Vol 13, Issue 11, 2020

\title{
PHYTOCHEMICAL SCREENING IN VITRO BIOLOGICAL ACTIVITIES AND ISOLATION OF ACTIVE MOLECULE FROM VITEX ALTISSIMA LEAVES
}

\author{
PREETHI NAIDU V ${ }^{1}$, VAGDEVI HM ${ }^{2 *}$, LATHA KP, AJISH AD ${ }^{1}$ \\ ${ }^{1}$ Department of Chemistry, Sahyadri Science College, Shivamogga, Karnataka, India. ${ }^{2}$ Department of Sahyadri Commerce and \\ Management College, Shivamogga Karnataka, India. Email: vagdevihm17@gmail.com
}

Received: 25 July 2020, Revised and Accepted: 05 September 2020

\section{ABSTRACT}

Objective: The objective of this work is to investigate the antibacterial, anthelmintic activity of the leaves of Vitex altissima and isolation of the bioactive molecule.

Methods: The agar disk diffusion method is implemented to evaluate the antibacterial activity of the plant leaves of $V$. altissima, using petroleum ether, ethyl acetate, and ethanol extracts. Exactly $1 \mathrm{mg}$ of each extract is dissolved in $1 \mathrm{ml}$ of dimethyl sulfoxide. The circular Whatman filter paper of diameter $5 \mathrm{~mm}$ was dipped in each extract and placed over solidified agar medium. The zone of inhibition was measured. The petroleum ether, ethyl acetate, and ethanol extracts of the plant have been used to carry out the anthelmintic activity against Indian earthworms Pheretima posthuma. The column chromatography technique is used for the isolation of bioactive molecules.

Results: The results revealed that the ethyl acetate extract exhibited a remarkable zone of inhibition against Gram-positive and Gram-negative bacteria. The petroleum ether, ethyl acetate, and ethanol extracts produce zero percentage zone of inhibition against Escherichia coli bacteria. The ethanol extract showed potent anthelmintic activity. The spectral data confirm that the structure of the bioactive molecule is 4 -hydroxybenzoic acid.

Conclusion: The preliminary results of the study revealed that the ethyl acetate extract of the plant exhibited a broad zone of inhibition against various Gram-positive and Gram-negative bacterial strains and ethanol extract showing significant anthelmintic activity. Spectral data confirmed the structure of the bioactive molecule. The obtained bioactive molecule is responsible for exhibiting potent antibacterial activity.

Keywords: Vitex altissima, Verbenaceae, Phytochemical constituents, Antibacterial, Anthelmintic activity, Pheretima posthuma, Column chromatography.

(C) 2020 The Authors. Published by Innovare Academic Sciences Pvt Ltd. This is an open access article under the CC BY license (http://creativecommons. org/licenses/by/4. 0/) DOI: http://dx.doi.org/10.22159/ajpcr.2020.v13i11.39222

\section{INTRODUCTION}

Plants are the essential foundation of medicine. Some important drugs that are still in use today are derived from conventional medicinal herbs. Plants and their active constituents play a vital role in the prevention of a variety of diseases. Numerous medicinal plants have been identified and modern scientific tools are used to study their authenticity, safety, and efficacy of their therapeutic use. The results revealed the great potential of medicinal plants in the field of pharmacology. Helminthiasis is among the most important animal diseases inflicting heavy production losses. Helminthes are the most common infectious agent of humans in developing countries and which produce a global burden of disease and contribute to the prevalence of malnutrition, anemia, eosinophilia, and pneumonia. The disease is highly prevalent, particularly in third world countries, due to poor management practices [1]. However, increasing problems of development of resistance in helminths against anthelmintics have led to the proposal of screening medicinal plants for their anthelmintic activity $[2,3]$. The plants are known to provide a rich source of botanical anthelmintics $[4,5]$

The genus Vitex includes nearly 270 known species of trees. Vitex altissima commonly known as a peacock chaste tree. It belongs to the family Verbenaceae. It is usually found in the countries of Indo-Malaysian region - Bangladesh, India, Indonesia, Myanmar, Papua New Guinea, and Sri Lanka. It is a woody plant reaching $20 \mathrm{~m}$ height. The leaves are trifoliate or palmate, compound, and opposite. The inflorescences are in terminal panicles. The corolla is bluish-white. The purplish-black fruit is a four seeded drupe [6]. The common names in Kannada are Myrole, Nevaladi, and Balgay. The bark of the plant is mainly used in the treatment of rheumatic swellings. The leaves and roots are used in Ayurvedic medicine [7]. It is used to treat inflammations, wounds, ulcers, allergies, worm infections, urinary system diseases, stomatitis, cardiac diseases, anorexia, blindness, and leprosy. Therefore, the present study has been undertaken to explore chemical constituents and the antibacterial and anthelmintic activities of petroleum ether, ethyl acetate, and ethanolic extract of $V$. altissima leaves.

\section{METHODS}

\section{Collection of plant materials}

The specimens were collected from Hosanagara Taluk, Shivamogga District, Karnataka, India. The plant was authenticated by the taxonomist. A voucher specimen (KU/SSC-53/2017) was deposited in the Department of Biotechnology, Sahyadri Science College, Kuvempu University, Shivamogga.

\section{Processing of plant material}

The leaves of the selected plant were collected in the month of August. The leaves were washed in running water, sprayed ethanol to avoid fungus, and chopped into small pieces, this was shade dried over a period of 3 weeks. The dried leaves were milled into a fine powder by the mixer. The powder stored in clean polythene bags in a cool, dry place until further use.

\section{Extraction of plant material}

About $0.5 \mathrm{~kg}$ of dried, powdered material was successively extracted with petroleum ether, ethyl acetate, and ethanol using a hot Soxhlet extractor. The plant material was processed with different solvents such as petroleum ether, ethyl acetate, and ethanol. Finally, the obtained solvent extracts were reduced using a rotary evaporator and 
dried. The dried extracts were weighed and kept in labeled specimen glass bottles.

\section{Preliminary phytochemical screening}

The obtained petroleum ether, ethyl acetate, and ethanol extracts of the plant were analyzed for the presence of phytoconstituents such as carbohydrates, flavonoids, alkaloids, coumarins, reducing sugars, tannins, saponins, proteins, and steroids using a standard protocol [8-11].

\section{Antibacterial activity}

Test microorganisms

The test bacterial strains were endowed by the Department of Microbiology, Jnana Sahyadri Kuvempu University. Staphylococcus aureus, Escherichia coli, Bacillus subtilis, Klebsiella pneumonia, and Agrobacterium tumefaciens bacterial strains have been used to assess the antimicrobial activity.

\section{Disk diffusion method}

Antibacterial activity was carried out by the disk diffusion method [12]. The petroleum ether, ethyl acetate, and ethanol extracts were dissolved in dimethyl sulfoxide (DMSO) at a concentration of $1000 \mu \mathrm{g} / \mathrm{ml}$. The plates are prepared by pouring $15 \mathrm{ml}$ of molten nutrient agar media into sterile Petri plates. The Petri plates were allowed to solidify for $5 \mathrm{~min}$, and $0.1 \%$ inoculums suspension was swabbed uniformly using sterile cotton swabs and allowed to dry. Whatman filter paper no.1 disk of $5 \mathrm{~mm}$ diameter was impregnated with $10 \mu \mathrm{L}$ of the solution of crude extracts which were placed on the surface of the media. Two control disks were used DMSO as control and chloramphenicol as a standard, respectively. The plates were incubated for $24 \mathrm{~h}$ at $37^{\circ} \mathrm{C}$. The experiments were performed in duplicate. The zone of inhibition was measured.

\section{Anthelmintic activity}

Petroleum ether, ethyl acetate, and ethanol extracts from the leaves of $V$. altissima have been investigated for anthelmintic activity against Pheretima posthuma. The anthelmintic activity was performed on adult Indian earthworms, Pheretima posthuma, due to its anatomical and physiological resemblance with that of intestinal roundworm parasite of human beings [13-18]. Tannins and flavonoids are polyphenolic compounds, were shown to produce anthelmintic activities $[19,20]$. Various concentrations of each extract were tested, the time of paralysis and time of death of earthworms was recorded. Tween-80 (1\%) in normal saline served as control and albendazole as a standard.

The earthworms were collected from Earthworm rearing Centre, Dummalli, Shivamogga, Karnataka. The earthworms are washed with normal water to remove adhering soil particles. The worms of
6-8 $\mathrm{cm}$ in length were selected as per the experimental protocol. The earthworms were kept in $6 \%$ dextrose in 10 min for normal motility. All the worms of equal size were divided into 11 groups and each group contains three worms. Group I was treated with vehicle $(1 \%$ Tween-80 in normal saline) served as a control, Group II is treated with albendazole (standard), and Groups III-XI were treated with different concentrations $(20 \mathrm{mg} / \mathrm{ml}, 40 \mathrm{mg} / \mathrm{ml}$, and $60 \mathrm{mg} / \mathrm{ml}$ in normal saline containing $1 \%$ Tween-80) of all the three extracts. The time taken for paralysis and death of the earthworms was recorded. The time for paralysis (in min) was noted when no movement of any sort could be observed except when the worms were shaken vigorously. Death was confirmed when the earthworms lost their motility even when dipped in hot water followed by fading their body color.

\section{Isolation of ethyl acetate extract of $V$. altissima leaves}

The leaves of $V$. altissima were subjected to Soxhlet extraction using solvents petroleum ether, ethyl acetate, and ethanol in the increasing order of their polarity. The obtained extracts were screened for antibacterial and anthelmintic activities. The results showed that the ethyl acetate extract exhibited a remarkable zone of inhibition against Gram-positive and Gram-negative bacterial strains. Therefore, the ethyl acetate extract was considered for the isolation of crude extract. In the present study, the following techniques were adopted to achieve the isolation of pure component.

-Thin-layer chromatography (TLC).

- Conventional column chromatography.

The ethyl acetate extract $(3.0 \mathrm{~g})$ was subjected to column chromatography on silica gel column. The column was eluted initially with petroleum ether followed by a mixture of petroleum ether and ethyl acetate in various proportions. Fractions were collected in $100 \mathrm{ml}$ portions and monitored by TLC and the fractions with similar spots are pooled together. A green solid mass is obtained after concentrating the solution for $24 \mathrm{~h}$ at room temperature. The green substance was recrystallized from petroleum ether. Among the obtained fractions, fraction $\mathbf{5}$ has found in high yield with purity. Hence, it has been considered for characterization.

Table 1: Crude extracts obtained from Vitex altissima leaves of various solvents

\begin{tabular}{llll}
\hline Extracts & $\begin{array}{l}\text { Weight } \\
\text { taken in' Kg' }\end{array}$ & $\begin{array}{l}\text { Appearance of } \\
\text { extracts }\end{array}$ & $\begin{array}{l}\text { Weight } \\
\text { obtained in' g' }\end{array}$ \\
\hline Petroleum ether & 0.5 & Semi solid (green) & 8.2 \\
Ethyl acetate & & Semi solid (green) & 12.5 \\
Ethanol & & Paste (brown) & 21.6 \\
\hline
\end{tabular}

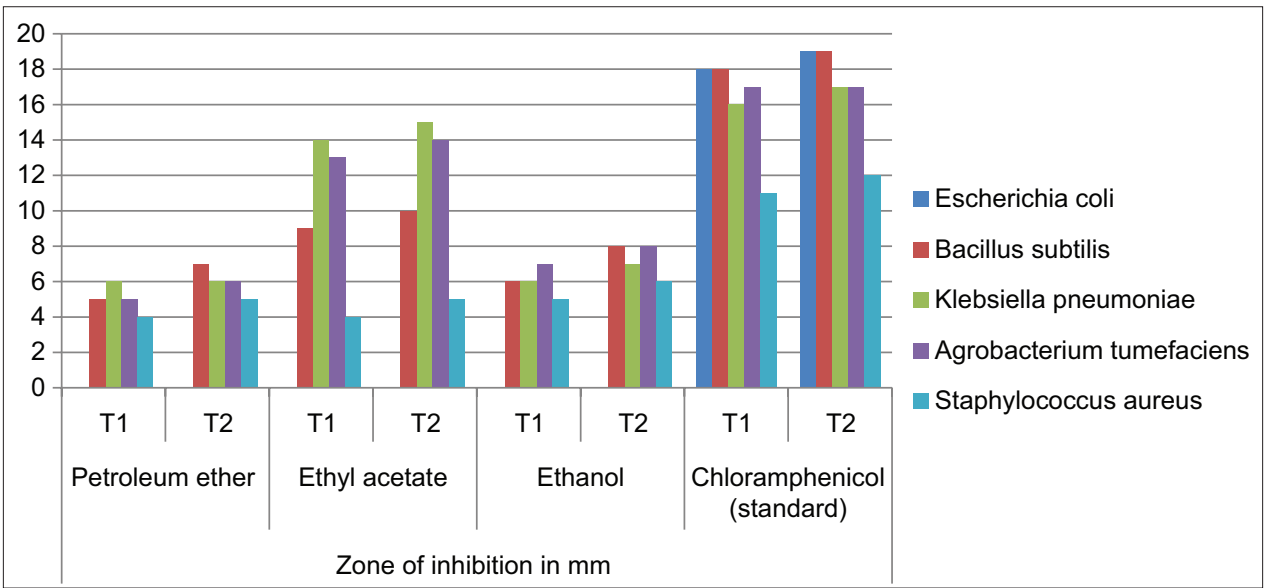

Fig. 1: Antibacterial activity of Vitex altissima 
Characterization of isolated compound from ethyl acetate extract of $V$. altissima leaves

The structure of the isolated component is

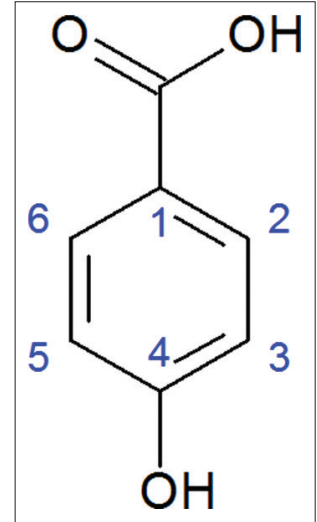

The isolated compound which is a green solid was characterized by physical parameters such as melting point and spectral studies.

\section{RESULTS AND DISCUSSION}

The presence of various phytochemical constituents is represented in Table 2. Plant extract of $V$. altissima revealed a good source of secondary metabolites such as flavonoids, terpenoids, saponins, carbohydrates, alkaloids, reducing sugars, and steroids. The antimicrobial activity results were tabulated in (Table 3 and Fig. 1). The plant extracts show zero zones of inhibition against E. coli. Ethyl acetate extract exhibited a significant value against bacterial strains $K$. pneumonia $15 \mathrm{~mm}$ and $A$. tumefaciens $14 \mathrm{~mm}$ as compared with the standard drug chloramphenicol $17 \mathrm{~mm}$. The petroleum ether and ethanol extracts show a weak zone of inhibition against S. aureus, B. subtilis, K. pneumonia, and $A$. tumefaciens. The ethanolic extract of $V$. altissima exhibited potent anthelmintic activity at the concentration of $60 \mathrm{mg} / \mathrm{ml}$. The paralysis time was $43 \mathrm{~min}$ and mean death time was $70 \mathrm{~min}$ as compared with the standard drug albendazole. The concentration of $60 \mathrm{mg} / \mathrm{ml}$ of the albendazole showed paralysis at $38 \mathrm{~min}$ and for mean death time is 65 min. The results of anthelmintic activity were tabulated in Table 4. The chromatographic result details of $V$. altissima leaves have shown in Table 5. Fraction $\mathbf{5}$ has found in high yield. This was considered for

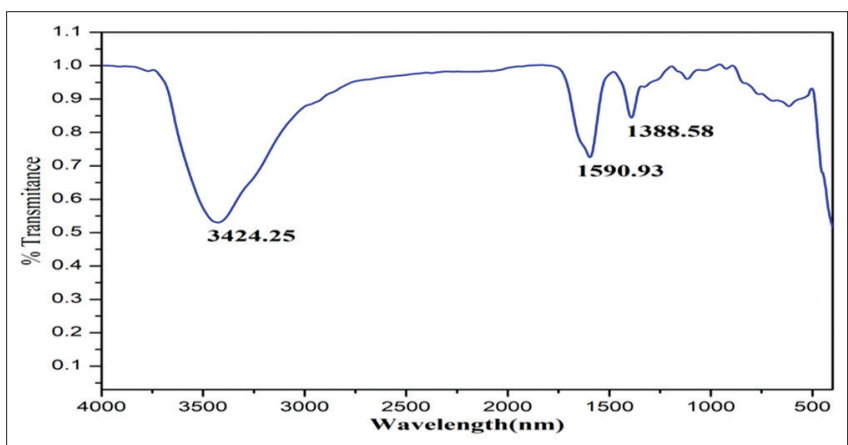

Fig. 2: Infra-red spectra of 4- hydroxybenzoic acid

Table 2: Result of phytochemical constituents of petroleum ether, ethyl acetate, and ethanol extracts of Vitex altissima

\begin{tabular}{|c|c|c|c|c|c|c|c|c|c|}
\hline Constituents & Carbohydrates & Tannins & Saponins & Alkaloids & Reducing sugars & Flavonoids & Steroids & Coumarins & Proteins \\
\hline Petroleum ether & + & - & - & - & + & - & - & - & - \\
\hline Ethyl acetate & + & + & - & - & + & + & - & - & - \\
\hline Ethanol & + & + & + & + & + & + & + & - & + \\
\hline
\end{tabular}

+: Presence, -: Absence

Table 3: Antibacterial activity of Vitex altissima extracts

\begin{tabular}{|c|c|c|c|c|c|c|c|c|}
\hline \multirow[t]{3}{*}{ Bacterial stains } & \multicolumn{8}{|c|}{ Zone of inhibition in $\mathrm{mm}$} \\
\hline & \multicolumn{2}{|c|}{ Petroleum ether } & \multicolumn{2}{|c|}{ Ethyl acetate } & \multicolumn{2}{|c|}{ Ethanol } & \multicolumn{2}{|c|}{ Chloramphenicol (standard) } \\
\hline & T1 & $\mathrm{T} 2$ & T1 & T2 & T1 & T2 & T1 & T2 \\
\hline Escherichia coli & - & - & - & - & - & - & 18 & 19 \\
\hline Bacillus subtilis & 5 & 7 & 9 & 10 & 6 & 8 & 18 & 19 \\
\hline Klebsiella pneumonia & 6 & 6 & 14 & 15 & 6 & 7 & 16 & 17 \\
\hline Agrobacterium tumefaciens & 5 & 6 & 13 & 14 & 7 & 8 & 17 & 17 \\
\hline
\end{tabular}

Table 4: Anthelmintic activity of the extracts of Vitex altissima

\begin{tabular}{llll}
\hline Extracts & $\begin{array}{l}\text { Concentration } \\
\mathbf{m g} / \mathbf{m l}\end{array}$ & $\begin{array}{l}\text { Paralysis } \\
\text { time } \mathbf{( m i n} \text { ) }\end{array}$ & $\begin{array}{l}\text { Death time } \\
\text { (min) }\end{array}$ \\
\hline Petroleum ether & 20 & 100 & 120 \\
& 40 & 78 & 102 \\
Ethyl acetate & 60 & 65 & 98 \\
& 20 & 89 & 106 \\
Ethanol & 40 & 60 & 86 \\
& 60 & 49 & 68 \\
& 20 & 88 & 102 \\
Albendazole & 40 & 56 & 85 \\
& 60 & 43 & 70 \\
Control & 20 & 76 & 98 \\
& 40 & 55 & 82 \\
& 60 & 38 & 65 \\
& - & - & -
\end{tabular}

Table 5: The chromatographic details of the ethyl acetate extract of Vitex altissima leaves

\begin{tabular}{llll}
\hline Fractions & $\begin{array}{l}\text { Mobile phase (petroleum } \\
\text { ether+ethyl acetate) }\end{array}$ & $\begin{array}{l}\text { Color and } \\
\text { nature }\end{array}$ & Yield in mg \\
\hline 1 & 100 & No residue & negligible \\
2 & $90: 10$ & No residue & negligible \\
3 & $85: 15$ & Pale yellow & negligible \\
4 & $80: 20$ & Pale brown & negligible \\
5 & $78: 22$ & Green solid & $50^{*}$ \\
6 & $70: 30$ & Green solid & negligible \\
7 & $60: 40$ & No residue & negligible \\
8 & $50: 50$ & No residue & negligible \\
9 & $40: 60$ & No residue & negligible \\
10 & $30: 70$ & Pasty brown & negligible \\
11 & $20: 80$ & Pasty brown & 13 \\
12 & $10: 90$ & Pasty brown & negligible \\
13 & 100 & Pasty brown & negligible \\
\hline
\end{tabular}




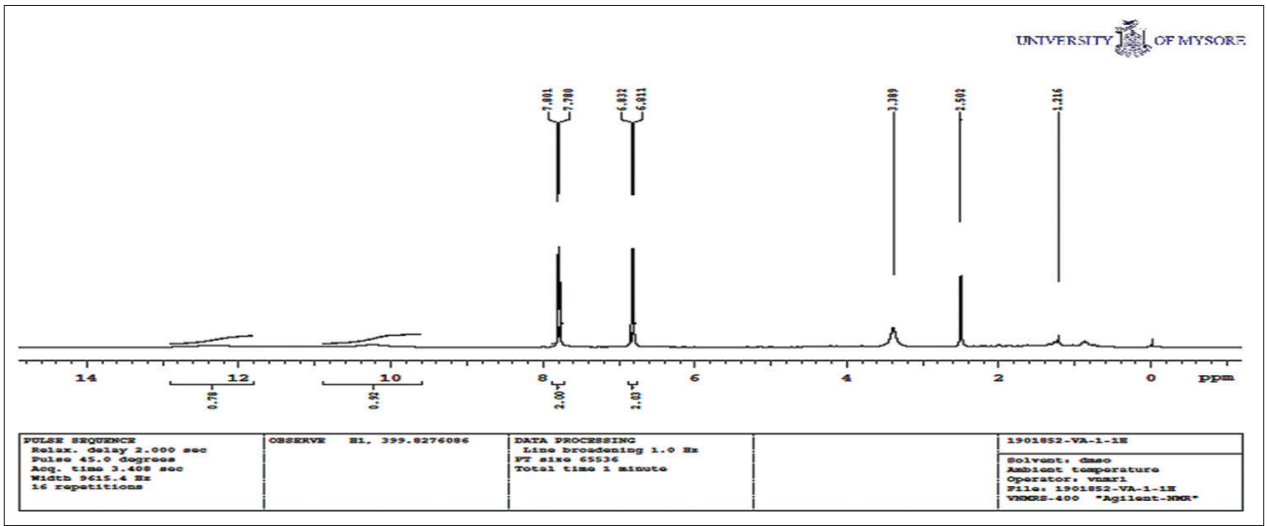

Fig. 3: Nuclear magnetic resonance spectra of 4- hydroxybenzoic acid

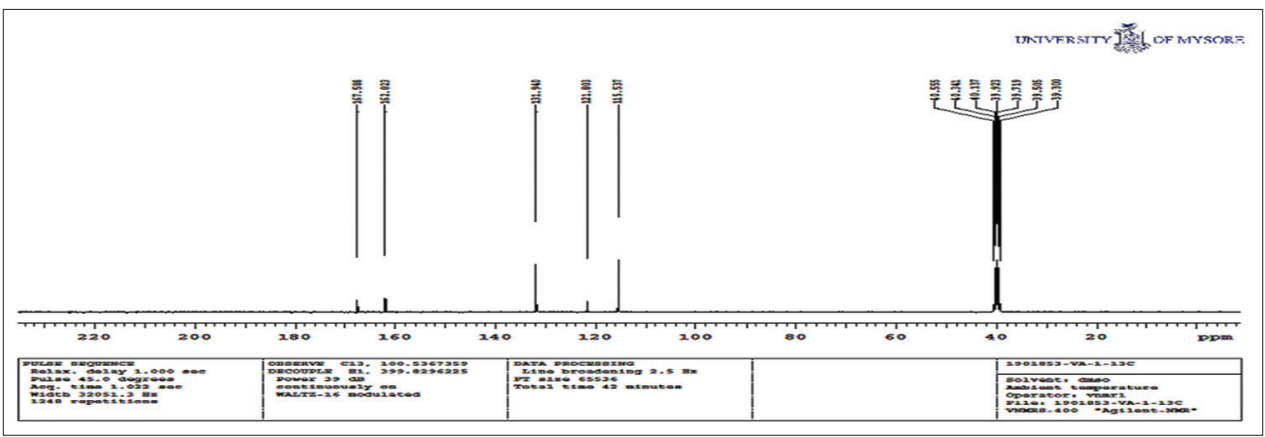

Fig. 4: ${ }^{13} \mathrm{C}$ NMR spectra of 4- hydroxybenzoic acid

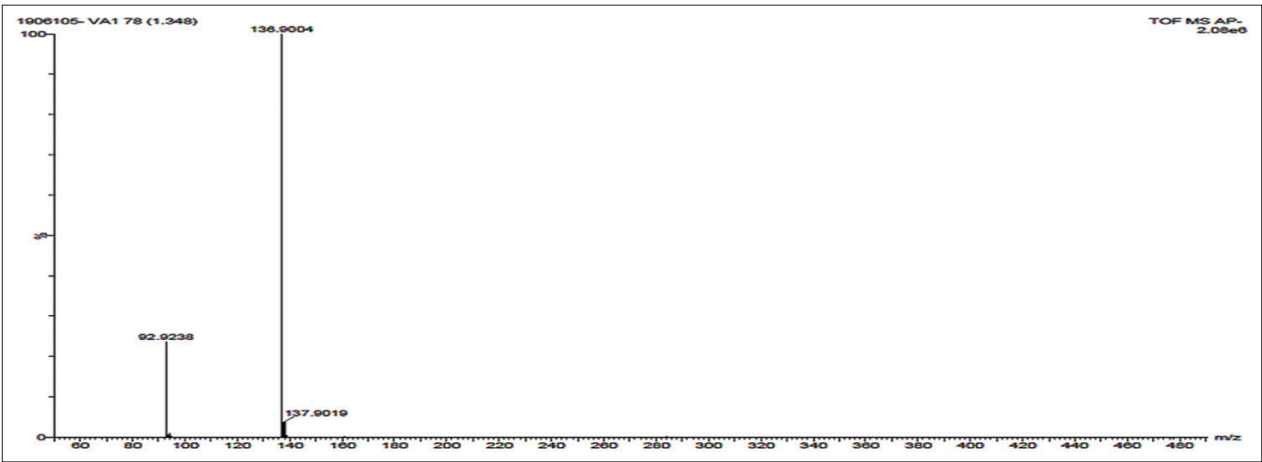

Fig. 5: Mass spectra of 4- hydroxybenzoic acid

characterization. Appearance of broadband at $3424 \mathrm{~cm}^{-1}$ indicates the presence of the free hydroxyl group and at $1590 \mathrm{~cm}^{-1}$ for carbonyl group in the IR spectrum. The ${ }^{1} \mathrm{H}$ NMR and ${ }^{13} \mathrm{C}$ NMR spectral data confirm the structure of the bioactive molecule. The mass of the bioactive molecule was found to be (LC-MS) $\mathrm{m} / \mathrm{z}=137.9019$. The spectral data confirm the structure of the bioactive molecule as 4-hydroxybenzoic acid. The spectral details were represented in (Figs. 2-5).

\section{Melting point}

Melting point was recorded in an open capillary tube. The melting point of the component is $215-218^{\circ} \mathrm{C}$.

\section{Infrared spectroscopy}

IR spectra were recorded on an FTIR Shimadzu spectrophotometer $\mathrm{KBr}$ pellet; $v$ in $\left(\mathrm{cm}^{-1}\right)$. The IR spectrum of $\mathbf{5}$ showed bands at broadband at $3424.25 \mathrm{~cm}^{-1}$ for free hydroxyl group (-OH), $1590.93 \mathrm{~cm}^{-1}$ for carbonyl group $(\mathrm{C}=0)$.

\section{Nuclear magnetic resonance spectroscopy}

The ${ }^{1} \mathrm{H}$ NMR and ${ }^{13} \mathrm{C}$ NMR spectra were recorded in DMSO-d6 solvent on 400MR DD2 Agilent. The ${ }^{1} \mathrm{H}$ and ${ }^{13} \mathrm{C}$ chemical shifts are reported on the $\delta$ scale in ppm, relative to tetramethylsilane (TMS) as an internal standard. ${ }^{1} \mathrm{H}$ NMR spectrum of the compound $\mathbf{5}$ exhibited two doublet peaks at $\delta 6.81(2 \mathrm{H}, J=8.76)$ and $\delta 7.87(2 \mathrm{H}, J=8.80)$ equivalent to four protons due to the presence of disubstituted benzene ring. There is a broad peak at $\delta 10.2$ and $\delta 12.4$ indicates the presence of $-\mathrm{OH}$ and -COOH functionalities, respectively.

The ${ }^{13} \mathrm{C}$ NMR spectra of compound $\mathbf{5}$ exhibited total five signals, a signal $\delta 167.588$ assigned for the carbon of carboxylic acid. The four different signals at $\delta 121.803$ for C-2 and C-6, $\delta 131.940$ for C-4, $\delta 115.537$ for C-3 and C-5, and $\delta 162.0233$ assigned for C- 1 carbons of a benzene ring, respectively.

\section{Mass spectrometry}

Samples were analyzed on mass Q-TOF equipped with ESI ion source. The sample was analyzed in a positive mode and negative mode. The LC-MS $\mathrm{m} / \mathrm{z}=137.9019$. On the basis of spectral analysis and melting point, compound $\mathbf{5}$ is identified as 4 -hydroxybenzoicacid ( $p$-hydroxybenzoic acid). 


\section{CONCLUSION}

From this work, it is concluded that the plant $V$. altissima extracts are a great source of phytoconstituents and could be used for the isolation of active natural components. The result of the antimicrobial activity revealed that the ethyl acetate exhibited a remarkable zone of inhibition and ethanolic extract shown significant anthelmintic activity, which is mainly due to the active phytoconstituents present in the extracts. These results, therefore, support the traditional use of the plant. However, further studies are needed to examine the mechanisms of antibacterial and anthelmintic activities and to isolate the other active biomolecules, which are responsible for pharmacological activities.

\section{ACKNOWLEDGMENT}

The authors are thankful to the Principal, Sahyadri Science College, Shivamogga, for providing the necessary facilities to carry out research work.

\section{AUTHORS' CONTRIBUTIONS}

All authors have equally contributed to making this report to be ccessful.

\section{CONFLICTS OF INTEREST}

We declare no conflicts of interest for this research.

\section{AUTHORS' FUNDING}

The author herself bears the publication fees of this paper

\section{REFERENCES}

1. Dhar DN, Sharma RL, Bansal GC. Gastrointestinal nematodes in sheep in Kashmir. Vet Parasitol 1982;11:271-7.

2. Geert S, Dorny P. Anthelmintic resistance in helminthes of animals of man in the tropics: Bulletin-des-seances, academic-royale-dessciencesd. Dutre Mer 1995;3:401-23.

3. Coles GC. Nematode control practices and anthelmintic resistance on
British sheep farms. Vet Rec 1997;141:91-3.

4. Satyavati GV, Raina MK, Sharma M. Medicinal Plants of India. Vol. 1. New Delhi, India: Indian Council of Medical Research; 1976. p. 201-6.

5. Lewis WH, Lewis MP. Medicinal Botany Plants Affecting Man's Health. New York: John Wiley \& Sons; 1977.

6. Yoganarasimhan SN. Medicinal Plants of India. Vol. 2. Tamil Nadu: Cyber Media; 2000. p. 584.

7. Argueta A, Cano LM, Rodarte ME. Atlas de las Plantas de la Medicina Tradicionaliy. Vol. 3. Mexico: Instituto Nacional Indigenista; 1994. p. $537-8$.

8. Edeoga HO, Okwu DE, Mbaebie BO. Phytochemical constituents of some Nigerian medicinal plants. Afr J Biotech 2005;4:685-8.

9. Egwaikhide PA, Gimba C. Analysis of the phytochemical content and anti-microbial activity of Plectranthus glandulosis whole plant. Middle East J Sci Res 2007:2:135-8.

10. Harborne JB. Phytochemical Methods. A Guide to Modern Techniques of Plant Analysis. $3^{\text {rd }}$ ed. London: Chapman and Hall; 1998. p. 302.

11. Sazada S, Verma A, Rather AA, Jabeen F, Meghvansi MK. Preliminary phytochemicals analysis of some important medicinal and aromatic plants. Adv Biol Res 2009;3:188-95.

12. Gulluce M, Sahin F, Sokmen M, Ozer H, Daferera D, Sokmen A, et al. Antimicrobial and antioxidant properties of the essential oils and methanol extract from Mentha longifolia L. ssp. Longifolia. Food Chem 2007; $103: 1449-56$

13. Suresh V, Arunachalam G, Kumar NS. J Pharm Res 2011;4:283-4. 14. Vidyarthi RD. A Textbook of Zoology. 14 ${ }^{\text {th }}$ ed. New Delhi: Chand S and Co.; 1967.

15. Chatterjee KD. In: Ray G, editor. Parasitology, Protozoology and Helminthology. $6^{\text {th }}$ ed. Calcutta: Sree Saraswati Press Ltd.; 1967.

16. Sollmann T. Anthelmintics: Their efficiency as tested on earthworms. Pharmacol J Exp Ther 1918;12:120-70.

17. Das GK, Suresh P, Kar DM, Ganpaty S, Panda SB. Evaluation of Evolvulus alsinoides Linn. For anthelmintic and antimicrobial activities. J Nat Rem 2002;2:182-5.

18. Shivkar YM, Kumar VL. Anthelmintic activity of latex of Calotropis procera. Pharm Biol 2003;41:263-5.

19. Bate-Smith EC.. Linn J Soc Bot 1962;58:173-95.

20. Niezen JH, Waghorn GC, Charleston WA. Growth and gastrointestinal nematode parasitism in lambs grazing either lucerne Medicago sativa or Hedysarum coronarium, which contains condensed tannins. J Agric Sci 1995;125:281-9. 